\title{
Geochemical signature of aquitard pore water and its paleo-environment implications in Caofeidian Harbor, China
}

\author{
Jing Li, ${ }^{1,2}$ XING Liang, ${ }^{1,2 *}$ MengGui JiN ${ }^{1,2}$ and XUMeI MaO ${ }^{2}$ \\ ${ }^{1}$ State Key Laboratory of Biogeology and Environmental Geology, China University of Geosciences, \\ Wuhan 430074, China \\ ${ }^{2}$ School of Environment Studies, China University of Geosciences, Wuhan 430074, China
}

(Received May 25, 2012; Accepted December 27, 2012)

\begin{abstract}
Oxygen-18 $\left({ }^{18} \mathrm{O}\right)$, deuterium (D), and chemical patterns were determined in pore water samples extracted from $100-\mathrm{m}$ depth in Caofeidian Harbor, China. The stable isotopic composition indicates that aquitard pore water was of meteoric origin and was basically not influenced by evaporation. Seawater diffusion was identified as the main influence on the isotope signature of pore water, according to the $\delta^{18} \mathrm{O}$ profile and positive correlation between $\delta^{18} \mathrm{O}^{\text {and }} \mathrm{Cl}^{-}$. The chemistry of aquitard pore water is characterized by high total dissolved solids (TDS) decreasing with depth, ranging from 26.89 to $7.26 \mathrm{~g} / \mathrm{L}$. The same trend was observed for $\mathrm{Cl}^{-}, \mathrm{Na}^{+}$, and $\mathrm{Mg}^{2+}$, as influenced by seawater. However, the typical ion ratios (i.e., $\mathrm{Cl} / \mathrm{Br}, \mathrm{Sr} / \mathrm{Ba}$ ) of pore water change significantly in different sedimentary facies along the study profile due to the long-term reaction between pore water and sediment, further supporting the finding that pore water was not replaced by modern water or seawater. Therefore, during long-term aquitard residence, the chemical composition of pore water would be influenced by other processes such as reduction of sulfates and cation exchange. The rare earth elements (REEs) of pore water are mainly affected by water-rock interaction. The shale-normalized REE fractionation patterns display enrichment of heavy REEs (HREE) relative to light REEs (LREE) and even greater fractionation degree in marine sediment pore waters (as larger $\mathrm{La} / \mathrm{Yb}_{\mathrm{NASC}}$ ). The relative reduction environment in the aquitard and preferential mobilization of $\mathrm{Eu}^{2+}$ in the water-rock interaction lead to the development of positive Eu anomalies $\left(1.13<\left(\mathrm{Eu} / \mathrm{Eu}^{*}\right)_{\mathrm{NASC}}<1.98\right)$ and slightly positive Ce anomalies $\left(-0.13<\left(\mathrm{Ce} / \mathrm{Ce}^{*}\right)_{\mathrm{NASC}}<0.35\right)$.
\end{abstract}

Keywords: pore water, aquitard, origin, geochemistry, China

\section{INTRODUCTION}

Clay-rich aquitards are widespread throughout China, especially in the North China Plain. Due to their exceptionally low hydraulic conductivities and extensive areal distribution, they generally act as protective covers for regional aquifers (Yan et al., 2000; Rubel et al., 2002; Hendry and Wassenaar, 2011; Hiscock et al., 2011). Together with the large retention capacity of clays for cationic contaminants, this has brought aquitards into focus as potential host rocks for the geological disposal of radioactive and other waste (Kelln et al., 2001; Cherry et al., 2006; Savoye et al., 2008; Waber and Smellie, 2008). Alternatively, in many environmental programs, it was found that aquitard pore water, which usually contained heavy metals (Guerrero et al., 2005), has seriously polluted groundwater (McMahon and Chapelle, 1991; Parker et al., 2008; Jiao et al., 2010), particularly in subsidence regions, as extensive pumping can result in large volumes

\footnotetext{
*Corresponding author (e-mail: xliang@cug.edu.cn)
}

Copyright (c) 2013 by The Geochemical Society of Japan. of aquitard pore water flowing into adjacent aquifers (Lee and Byrne, 1992; Guo et al., 1995). Although aquitards play an important role in environment, geology, and hydrogeology, few studies have focused on the transport and geochemical reactions controlling solute concentrations in aquitards. Far less is presently known about aquitards than that of the behavior of solutes in aquifers (Hendry and Wassenaar, 2004; Timms and Hendry, 2008).

Unlike transport of solutes in aquifers, which is dominated by advection, the transport of conservative tracers (e.g., $\delta^{18} \mathrm{O}, \delta \mathrm{D}, \mathrm{Cl}^{-}$) in aquitards was shown to be dominated by molecular diffusion (Remenda et al., 1996; Guerrero et al., 1997; Hendry and Wassenaar, 1999). As pore water is retained for long periods within aquitards, its composition would be influenced by diagenetic processes (e.g., precipitation, adsorption, sulfide formation, remobilization, and biological degradation or uptake), causing the concentrations of chemical species in pore water to differ from free overlying water (Sacchi et al., 2001). Based on the weaker hydrodynamic condition and specific chemical composition, together with the stable isotope information (e.g., $\delta^{18} \mathrm{O}, \delta \mathrm{D}$, and $\delta^{13} \mathrm{C}$ ), aquitard pore water has been used in studies of groundwater ori- 
gin, hydrochemical evolution, and paleoclimate inversion (Hendry and Woodbury, 2007).

In previous studies of geochemical groundwater processes, rare earth elements (REEs) have been used as useful geochemical tracers (Dia et al., 2000; Guo et al., 2010; Hannigan et al., 2010). For example, Rönnback et al. (2008) suggested that the REE composition of groundwater showed extensive fractionation relative to the parent rocks as a result of processes involving dissolved organic matter complexes rather than carbonate complexes. Furthermore, changing the redox cycling of $\mathrm{Fe}$ and $\mathrm{Mn}$ appears to indirectly affect REE concentration and fraction patterns, owing to the different sorption ability and coprecipitation behavior of LREEs and HREEs (Augustsson et al., 2009; Biddau et al., 2009; Leybourne and Cameron, 2010). In addition, $\mathrm{Ce}$ and Eu have greater sensitivity to variations in redox conditions and their oxidation states will change from $\mathrm{Eu}^{3+}$ and $\mathrm{Ce}^{3+}$ to $\mathrm{Eu}^{2+}$ and $\mathrm{Ce}^{4+}$, respectively (Dia et al., 2000; Johannesson et al., 2011; Willis and Johannesson, 2011). Thus, anomalies in these elements have important implications regarding the redox state of a system (Sako et al., 2009).

The region of Caofeidian Harbor has relatively complex geological conditions and has experienced transgression many times since the late Pleistocene (Zhang et al., 1997). Due to the development of oil exploration and aquaculture and their associated surface-water contamination, extensive extraction of groundwater has resulted in seawater intrusion and subsidence in the area. An aquitard may play an important role in this process as it may separate the aquifer and also release pore water to the aquifer ( $\mathrm{Li}$ and $\mathrm{Li}, 2008$ ). The present study focuses on the geochemical signature of aquitard pore water and aims to (1) characterize the major ions, REE concentration, and stable isotope (i.e., $\delta \mathrm{D}, \delta^{18} \mathrm{O}$ ) of aquitard pore water along the tested depth profile, (2) determine the geochemical processes controlling the geochemical behavior of pore water, and (3) discuss the origin of aquitard pore water and its implications for the paleoenvironment.

\section{Geological ANd Hydrogeological SetTing}

The study site is located in Caofeidian Harbor, on the northwest shore of Bohai Bay, approximately $85 \mathrm{~km}$ southeast of Tangshan City, China (Fig. 1). Topographically, this site is part of a lagoon sand bank coast characterized by a well-developed offshore sand bank, shell sand embankment, lagoons, and tidal channels (Wang, 2000; Yan and Huo, 2007). The landscape units in this region are diverse, comprising tilted alluvial plains, alluvial-marine plains, and marine tidal flats from north to south (Fig. 1), which is mainly controlled by the development of the Luanhe River. Nowadays, the study area is little affected by the Luanhe River, sediments due to its diversion, and the loss of materials directly from the river (Wang et al., 1999).

Figure 1 shows the geology of the region for the profile $\mathrm{A}-\mathrm{A}^{\prime}$. The figure displays the depth of $120 \mathrm{~m}$ that we studied, but the total thickness of Quaternary sediments in this region is $\sim 420 \mathrm{~m}$. Holocene formation $\left(\mathrm{Q}_{4}\right)$ ranges from 3- to 20-m thick, comprising fine sand and silty sand (Chen, 2001). Epipleistocene formation $\left(\mathrm{Q}_{3}\right)$ ranges from $40-$ to $100-\mathrm{m}$ thick. Clayey rock and fine sand are interlayered deposited, and the clayey rock accounts for $\sim 58 \%$ of the total thickness. The mineralogical compositions of clay and sand are controlled by clay minerals (chlorite, illite, and kaolinite) that account for $48-66 \%$ of the total, followed by quartz, feldspar, calcite, and then dolomite.

In overview, the groundwater flow system, the study area is within the groundwater discharge zone of the Luanhe River basin. The main recharge sources are from rainfall infiltration and lateral runoff to the aquifer system, and discharge is dominated by evaporation and extraction. In vertical profile, the aquifers are characterized by a double structure, "the upper brackish water and lower fresh water," with the depth of the borderline gradually increasing from the west to east, down to $110 \mathrm{~m}$ at the study site (Li and Li, 2008; Zhang et al., 2010). The shallow brackish groundwaters (depth of 40-60 m, sand aquifer) are of $\mathrm{Cl}-\mathrm{Na}$ type, with salinity of $2-3 \mathrm{~g} / \mathrm{L}$. The depth of the water table is $\sim 2 \mathrm{~m}$. Deep groundwaters $(>120$ $\mathrm{m})$ in this area are $\mathrm{HCO}_{3}-\mathrm{Na}$ type waters, and total dissolved solids (TDS) are generally less than $0.5 \mathrm{~g} / \mathrm{L}$ (Zhang et al., 2010).

A total of 14 core samples (length: $20 \mathrm{~cm}$, diameter: 8 $\mathrm{cm}$ ) were collected by drilling, and geological features are shown in Fig. 2. The lithology of the samples is claybased, including sandy silt, silt, silty clay, and clay, with a water content of $17-30 \%$. The depth is $12.8-100 \mathrm{~m}$. We did not take samples from the thick sand layer of the uppermost $12.8 \mathrm{~m}$. To minimize soil disturbance and prevent oxidation and pore water evaporation, the core samples were collected with aluminum skin packaging and sealing wax and stored at $4^{\circ} \mathrm{C}$ prior to testing. The geological history of the borehole can be summarized as follows:

Not sampled $(0-12.8 \mathrm{~m})$ : yellow-grey fine sand was formed in the Holocene period $\left(\mathrm{Q}_{4}\right), \sim 10 \mathrm{ka} \mathrm{BP}$. The pore water is saline and seawater exists at the surface.

$\mathrm{T}_{1}$ formation (12.8-41.4 m): terrestrial sediment unit consists of dark grey silty clay, with iron specks in the upper and grey-yellow sandy silt and clay in the lower sections. This layer was formed during the glacial stage of the late Epipleistocene $\left(\mathrm{Q}_{3}{ }^{3}\right), \sim 10-30 \mathrm{ka} \mathrm{BP}$.

$\mathrm{M}_{1}$ formation (41.4-49.4 m): marine sediment unit consists of 5-m-thick sand in the upper and dark grey 

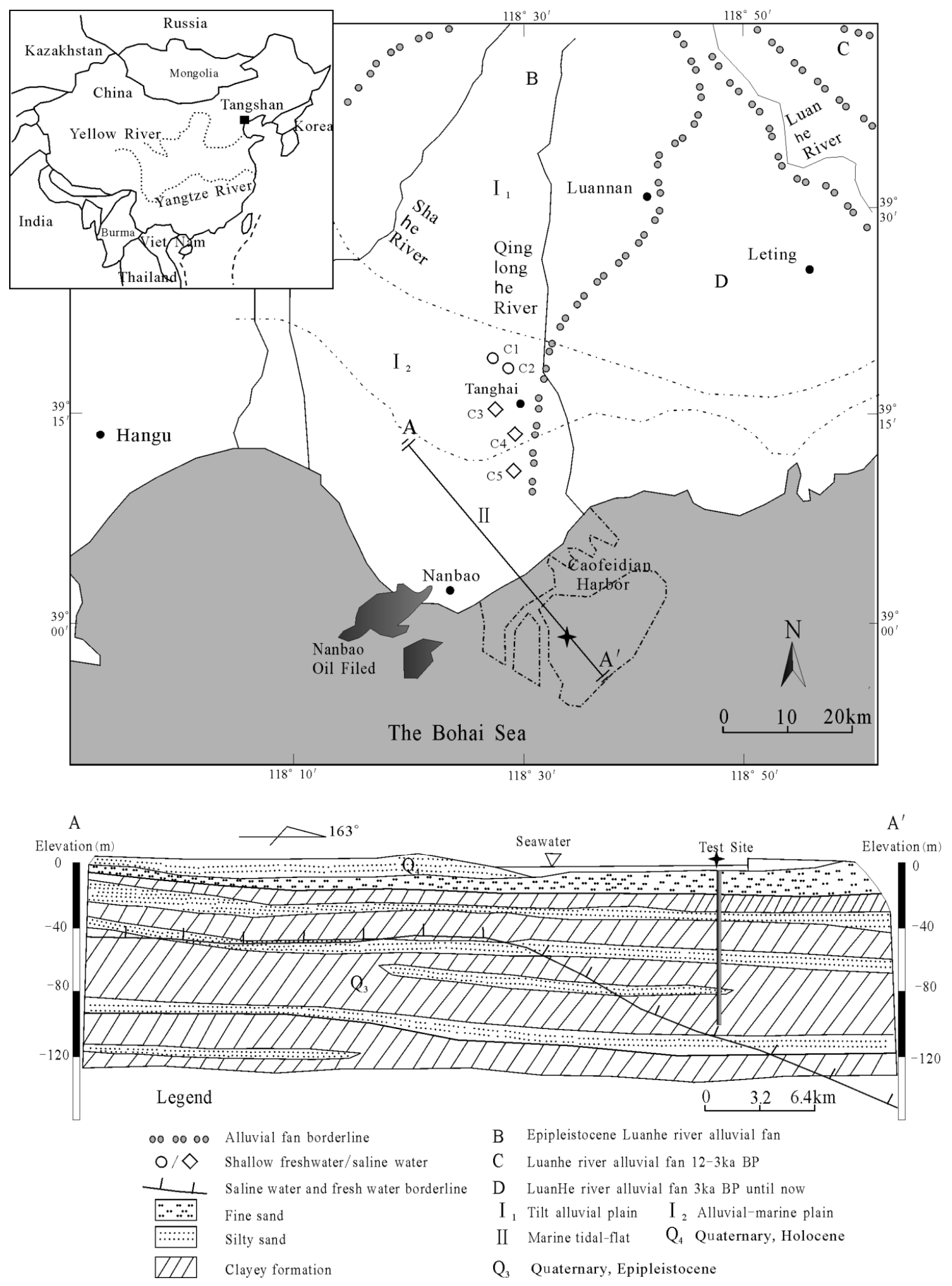

Fig. 1. Location map of the test site and a schematic geological cross section along the profile $A-A^{\prime}$ through the test site. 


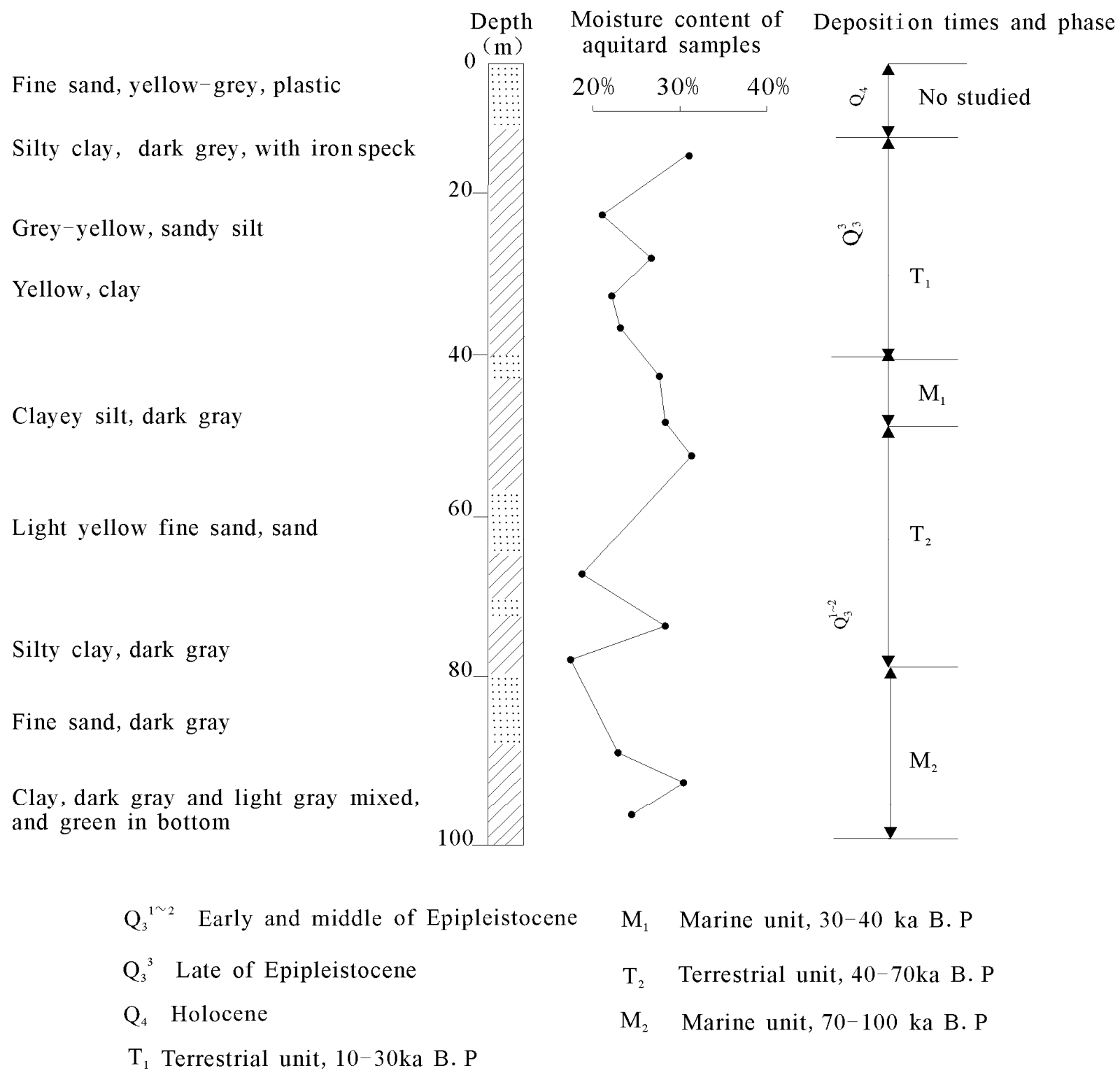

Fig. 2. Geology of the test borehole at the study site.

clayey silt in the lower sections. This layer was formed by the transgression in interglacial stage of the early and middle Epipleistocene $\left(\mathrm{Q}_{3}{ }^{1 \sim 2}\right), \sim 30-40 \mathrm{ka}$ BP.

$\mathrm{T}_{2}$ formation (49.4-79 m): In this terrestrial sediment unit, the lithology is mainly dark gray silt clay and $8.8-\mathrm{m}$ thickness of sand which is the shallow regional aquifer. This layer was formed during the glacial stage of the early and middle Epipleistocene $\left(\mathrm{Q}_{3}{ }^{1 \sim 2}\right), \sim 40-70 \mathrm{ka} \mathrm{BP}$.

$\mathrm{M}_{2}$ formation (79-100 $\mathrm{m}$ ): This marine sediment unit was formed in the Riss-Würm interglacial stage of the early and middle Epipleistocene $\left(\mathrm{Q}_{3}{ }^{1 \sim 2}\right), \sim 70-100 \mathrm{ka} \mathrm{BP}$. The upper is dark-grey fine sand and the bottom is dark clay.

\section{Pore Water Extraction Method and Analysis}

\section{Extraction of pore water}

Pore water was extracted from core samples using an ex situ mechanical squeezing method (Bufflap and Allen, 1995; Lopes and Ribeiro, 2005; Shen et al., 2011). The design of the squeezing device is based on high-pressure consolidation apparatus by adding water drainage and collection features (Shen et al., 2011). The advantages of this compression system are that (1) it avoids membrane damage, and the test depth is unlimited, compared to in situ methods (i.e., suction filtration, dialysis) (Yang et al., 2003); (2) it is inexpensive and simple to operate; and (3) it operates efficiently over a range of pressures 
(0-3 MPa), reducing the effect of high-pressure methods on pore water composition (Sacchi et al., 2001), for clay aquitard pore water extraction.

The crushed core samples $(\sim 1000 \mathrm{~g})$ were put in the inox chamber with a stress level of $2.12 \mathrm{MPa}$. The joints between the top (bottom) endplate and the inox chamber were sealed with O-rings. Core samples were compressed and consolidated for $48 \mathrm{~h}$; thus, pore water flowed out from the center hole of the bottom endplate and collected in the clean, dry plastic bottle, avoiding contact with the atmosphere. All the water samples were filtered through $0.45-\mu \mathrm{m}$ filters and refrigerated at $4{ }^{\circ} \mathrm{C}$. $~ 9-80 \mathrm{~mL}$ of pore water was extracted from each $1000 \mathrm{~g}$ sample, depending on the moisture content.

\section{Chemical and stable isotope analyses}

Pore water samples were analyzed for the major anions by ion chromatography (ICS-110). Alkalinity (as $\mathrm{HCO}_{3}{ }^{-}$) was determined using a titration method. For cation determination, the water was acidified with concentrated $\mathrm{HNO}_{3}$ to $\mathrm{pH}<2$ and analyzed by inductively coupled plasma atomic emission spectroscopy (ICP-AES, IRIS Intrepid II XSP). The analytical error is estimated to be $\sim 0.01 \mathrm{mg} / \mathrm{L}$ for all major ions.

Trace elements, including rare earth elements, were analyzed using inductively coupled plasma mass spectrometry (ICP-MS, Agilent 7500a), and the water samples were also acidified before testing. The REE isotopes $\left({ }^{139} \mathrm{La},{ }^{14} \mathrm{Ce},{ }^{141} \mathrm{Pr},{ }^{146} \mathrm{Nd},{ }^{147} \mathrm{Sm},{ }^{153} \mathrm{Eu},{ }^{157} \mathrm{Gd},{ }^{159} \mathrm{~Tb}\right.$, ${ }^{163} \mathrm{Dy},{ }^{165} \mathrm{Ho},{ }^{166} \mathrm{Er},{ }^{169} \mathrm{Tm},{ }^{174} \mathrm{Yb}$, and $\left.{ }^{175} \mathrm{Lu}\right)$ were free of elemental isobaric interferences (Johannesson and Hendry, 2000). The measured oxide yield $\mathrm{CeO}^{+} / \mathrm{Ce}$ was generally $<0.4 \%$, which is more accurate than the figure of $>1 \%$ reported in other studies (Stetzenbach et al., 1994; Johannesson et al., 1997). Interference from $\mathrm{BaO}^{+} / \mathrm{Ba}^{+}$ on Eu was less than $3 \%$ by extraction of $\mathrm{Ba}$ from aliquots of each sample using di-ethylhexyl phosphoric acid (Guo et al., 2010). REE standards of known concentration were tested every ten water samples, and then, the sample concentration was calibrated and verified. The detection limits were $1 \mathrm{ng} / \mathrm{L}$ for all trace elements.

Stable isotopes, ${ }^{18} \mathrm{O}$ and $\mathrm{D}$, were investigated by gas isotopic ratio mass spectrometry (Mat253). $\delta \mathrm{D}$ and $\delta^{18} \mathrm{O}$ are reported with respect to SMOW (standard mean ocean water), and the analytical reproducibility was better than $0.2 \%$ or ${ }^{18} \mathrm{O}$ and $2 \%$ for $\mathrm{D}$.

\section{RESULTS AND DISCUSSION}

\section{Stable isotope of aquitard pore water}

Stable isotopes, ${ }^{18} \mathrm{O}$ and $\mathrm{D}$ of nine aquitard pore water samples were tested, as the other samples yielded insufficient water volume (Table 1). Aquifer groundwater samples were not collected at the borehole location. At

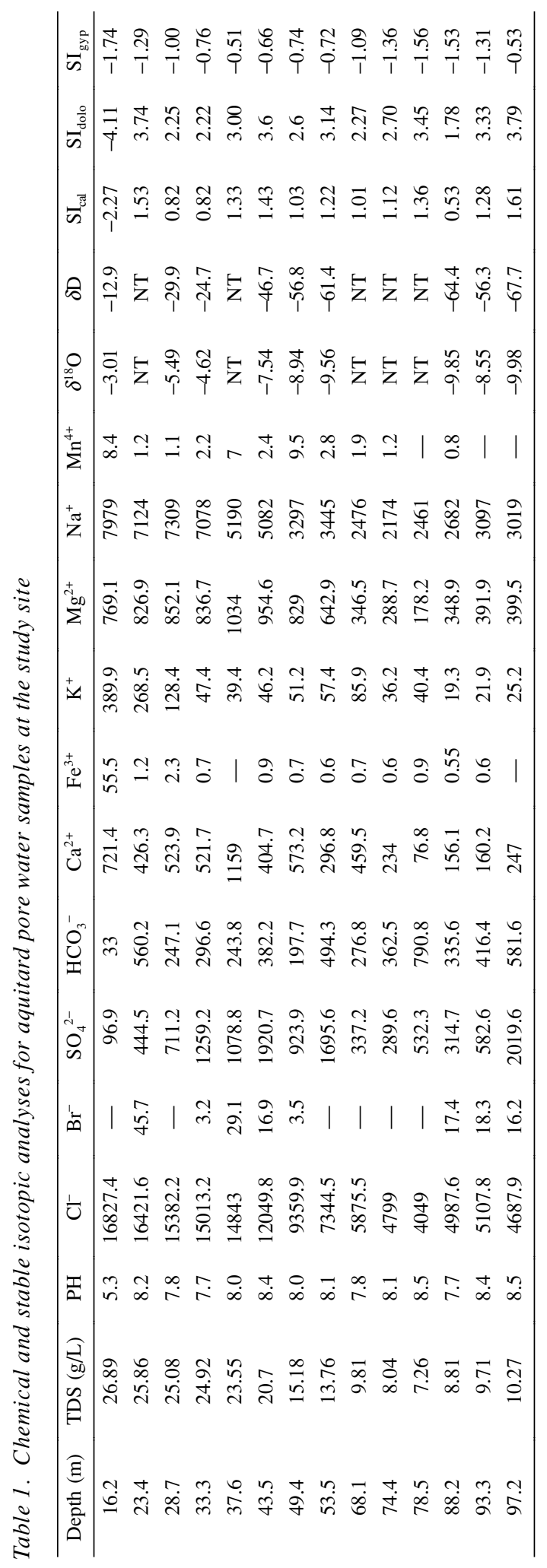




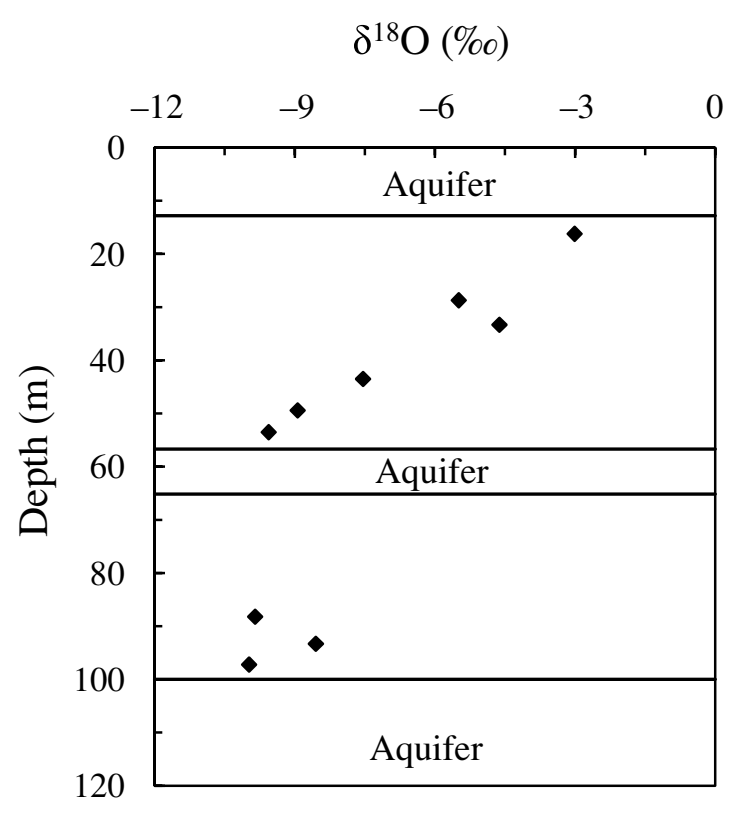

Fig. 3. Oxygen-18 profile of aquitard pore water.

Tanghai, five shallow groundwater samples were analyzed from the regional aquifer (Fig. 1). Two freshwater samples were obtained beneath the aquitard, $\mathrm{C} 1$ and $\mathrm{C} 2$, at a depth of $80 \mathrm{~m}$. At the borehole location, the same aquifer is located at a depth of $\sim 110 \mathrm{~m}$. Three saline water samples caused by seawater intrusion $(\mathrm{C} 3, \mathrm{C} 4$, and $\mathrm{C} 5)$ were collected at a depth of $10 \mathrm{~m}$ overlying the aquitard. A Bohai seawater sample was also analyzed.

Groundwater flowed from north to south in the study area, consistent with the surface water. Due to overextraction of groundwater, depression cones have formed in the areas of Fengnan, Tanghai, and Leting in response to the lowering of groundwater level, causing groundwater intrusion from surrounding aquifers (Wang et al., 1999). The five shallow groundwater samples in the flow direction from sea to the depression cones and the isotopic data are more depleted than the water at the borehole location as this is less influenced by seawater intrusion.

The vertical profile of aquitard pore water shows $\delta^{18} \mathrm{O}$ values of between $-3.03 \%$ and $-9.98 \%$, deceasing gradually with depth (Fig. 3). In the upper $16.2-33.3 \mathrm{~m}$, pore water $\delta^{18} \mathrm{O}$ values are similar to those of the saline water-for example, $\mathrm{C} 3$ and $\mathrm{C} 4$ (average $\delta^{18} \mathrm{O}=-3.75 \%$ ) (C5 was mixed with freshwater during drilling)—below which the $\delta^{18} \mathrm{O}$ values of pore water are much more depleted. Even at depths of $88.2-100 \mathrm{~m}$, pore water $\delta^{18} \mathrm{O}$ values are more depleted than those of upriver underlying freshwater $\left(\mathrm{C} 1\right.$ and $\mathrm{C} 2$, average $\delta^{18} \mathrm{O}=-7.96 \%$ ). Therefore, we consider that the isotopic composition of aquitard pore water was affected by seawater vertical diffusion not advection transport. In addition, the rela-

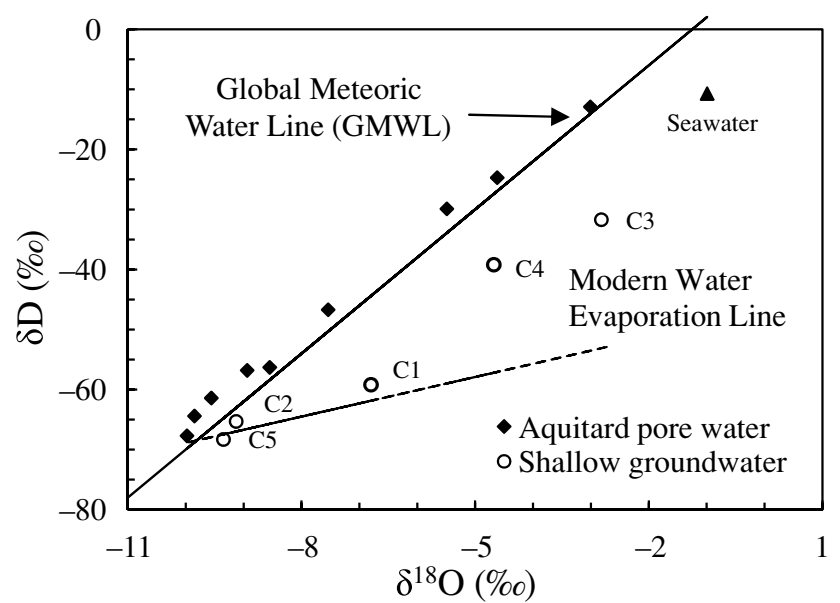

Fig. 4. Stable isotopic composition of aquitard pore water and shallow groundwater in Caofeidian Harbor $(C 1$ and $C 2$ are freshwater; C3, C4, and C5 are saline water; Evaporation Line is from Gao et al., 2004).

tionship between $\delta^{18} \mathrm{O}$ and $\mathrm{Cl}^{-}$(correlation coefficient: 0.93 ) shows that pore water $\delta^{18} \mathrm{O}$ values are enriched with increasing $\mathrm{Cl}^{-}$content (Table 1), which supports the role of seawater diffusion as the main mechanism in the isotope signature of aquitard pore water.

The diagram of isotope pore water data, plotted as $\delta^{18} \mathrm{O}$ versus $\delta \mathrm{D}$, shows a different pattern to that observed in samples of shallow groundwater (Fig. 4). Data for all of the pore water samples are plotted around the global meteoric water line (GMWL, Craig, 1961), indicating that these waters were originally of meteoric origin. Shallow groundwater samples C1, C2, and C5 are around the local modern water evaporation line (LMWEL), defined by Gao using 15 surface water samples, with the equation $\delta \mathrm{D}=2.2 \delta^{18} \mathrm{O}-46.9$ (Gao et al., 2004). Saline waters C3 and $\mathrm{C} 4$ are plotted above the LMWEL. It is expected that shallow freshwaters are mainly affected by evaporation, whereas saline waters are also subject to seawater intrusion.

Zhou et al. (1998) described that the age of shallow saline water is $\sim 1-4 \mathrm{ka}$ in western Bohai Bay. In this area, aquitard pore water $\delta^{18} \mathrm{O}$ values are more depleted than in shallow saline water, and deeper samples are more depleted than upriver freshwater, indicating that pore waters may be paleo-water owing to the low permeability of the clay-rich aquitard. However, the meteoric origin of pore water indicates that these waters are not coetaneous with the sediment. The late Epipleistocene is the most recent glacial maximum with a lower sea level of Bohai Bay. Upward flow of groundwater in this discharge zone may replace pore water. During the Holocene, groundwater flow direction changed as the sea level rose and infiltrated large areas. Intrusive seawater within aquifers 


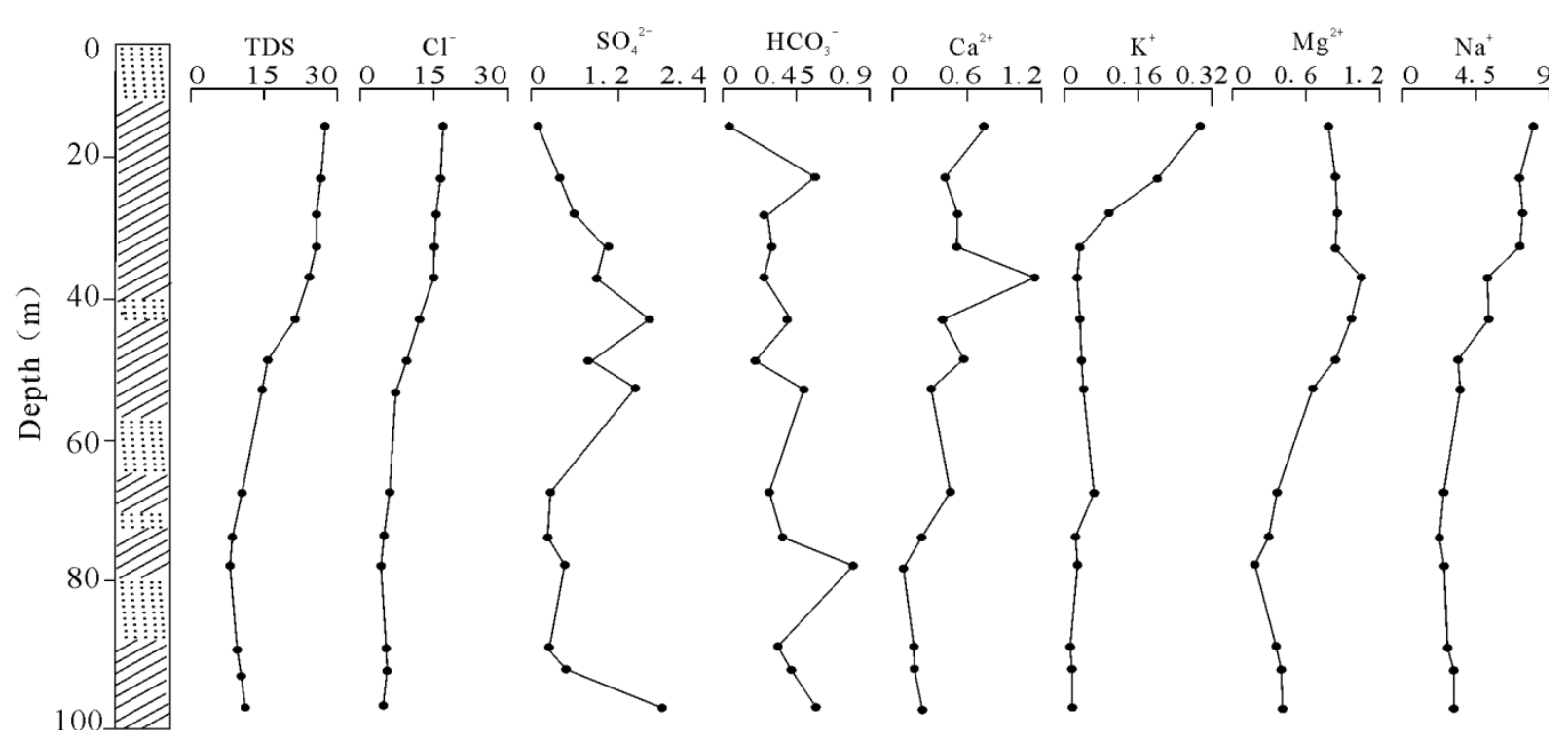

Fig. 5. TDS and major ions of aquitard pore water (Unit: $g / L$ ).

may diffuse into the clayey aquitard and, owing to the low velocity of diffusion. Pore water is not replaced by saline water or seawater, as indicated by the vertical profile of isotopic composition.

\section{Major ions of aquitard pore water}

Major ion concentrations $\left(\mathrm{Cl}^{-}, \mathrm{Br}^{-}, \mathrm{SO}_{4}{ }^{2-}, \mathrm{HCO}_{3}{ }^{-}\right.$, $\mathrm{Na}^{+}, \mathrm{K}^{+}, \mathrm{Mg}^{2+}, \mathrm{Ca}^{2+}, \mathrm{Fe}^{3+}$, and $\left.\mathrm{Mn}^{4+}\right), \mathrm{pH}$, and TDS of pore water are presented in Table 1. All the pore water samples along the study profile are saline water, with TDS of 7.26-26.89 g/L, which is $\sim 3-10$ times that of the local shallow groundwater (TDS $=2-3 \mathrm{~g} / \mathrm{L}$ ), and more than 15-53 times that of local deep groundwater. The $\mathrm{pH}$ of pore water is alkaline (7.7-8.5), except the shallowest water sample at $16.2-\mathrm{m}$ depth, in which the $\mathrm{pH}$ of 5.3 is caused by infiltration of surface industrial wastewater. The acidic environment led to the dissolution of clay minerals (e.g., chlorite and illite). Hence, the Fe content in the pore water reaches $55.5 \mathrm{mg} / \mathrm{L}$ at a depth of $16.2 \mathrm{~m}$, and it is less than $2.3 \mathrm{mg} / \mathrm{L}$ for deeper samples. The aquitard pore water is generally of $\mathrm{Cl}-\mathrm{Na}$ type, but it is of $\mathrm{Cl}-\mathrm{Na} \cdot \mathrm{Mg}$ type for depths of 37.6-53.5 m.

As $\delta^{18} \mathrm{O}$ revealed, the vertical chemical profiles of aquitard pore water also show the diffusion of seawater. The TDS of pore water exhibits a well-defined decreasing trend with increasing depth, from $26.89 \mathrm{~g} / \mathrm{L}$ at 16.2$\mathrm{m}$ depth close to seawater to $10.27 \mathrm{~g} / \mathrm{L}$ at $97.2-\mathrm{m}$ depth. A similar trend was observed for $\mathrm{Cl}^{-}, \mathrm{Na}^{+}$, and $\mathrm{Mg}^{2+}$, with linear correlation coefficients of $0.96,0.99$, and 0.88 ( $n$ =14), respectively (Fig. 5). $\mathrm{K}^{+}$decreases with depth from $389 \mathrm{mg} / \mathrm{L}$ at $16.2 \mathrm{~m}$ to $47.4 \mathrm{mg} / \mathrm{L}$ at $33.3 \mathrm{~m}$, below which the $\mathrm{K}^{+}$concentration remains constant. $\mathrm{SO}_{4}{ }^{2-}, \mathrm{HCO}_{3}{ }^{-}$, and
$\mathrm{Ca}^{2+}$ show large variations with depth and a weak covariation with TDS, which may be controlled by the distinct geochemical behavior in the sedimentary environment.

$\mathrm{Cl} / \mathrm{Br}$ and $\mathrm{Sr} / \mathrm{Ba}$ ratios As discussed above, pore waters are not replaced by modern water or seawater. In this case, pore water will be resident in the aquitard for a long time, reaching the equilibrium state of water-rock interaction. The chemical components of pore water will be determined by the different characteristics of the sediment. Here, we use the $\mathrm{Cl} / \mathrm{Br}$ and $\mathrm{Sr} / \mathrm{Ba}$ ratios to analyze the pore water chemistry owing to their distinct concentration in marine and terrestrial sediments (An et al., 1982).

$\mathrm{The} \mathrm{Cl} / \mathrm{Br}$ and $\mathrm{Sr} / \mathrm{Ba}$ ratios of Bohai seawater are 146.38 and 5.78, respectively (data not listed). As shown in Fig. 6, the $\mathrm{Cl} / \mathrm{Br}$ ratio of pore water describes obvious vertical zoning with depth: (i) In $\mathrm{T}_{1}$ formation (16.2-37.6 $\mathrm{m})$ and $\mathrm{T}_{2}$ formation $(53.5-78.5 \mathrm{~m}), \mathrm{Cl} / \mathrm{Br}$ ratios reach 4750 or tend to infinity (empty circles indicate $\mathrm{Br}^{-}$below the detection limit), showing a good correlation with terrestrial sediment unit. This results from the reaction between pore water and terrestrial sediment, in which $\mathrm{Br}^{-}$ content is much lower. The diffusion of seawater is mainly with $\mathrm{Na}^{+}$and $\mathrm{Cl}^{-}$. However, there is an important exception: the $\mathrm{Cl} / \mathrm{Br}$ ratio of 359 in pore water of $23.4-\mathrm{m}$ depth is a result of infiltration of adjacent sand layer groundwater, which has been completely intruded by seawater ( $\mathrm{Li}$ and $\mathrm{Li}, 2008$ ); (ii) $\mathrm{In}_{1}$ formation (37.6-49.4 m) and $\mathrm{M}_{2}$ formation (88.2-97.2 $\mathrm{m}$ ), pore water $\mathrm{Cl} / \mathrm{Br}$ ratios of 510 to 2713 , and 279 to 289 , respectively, correspond with this marine sediment, showing the long-term reaction between pore water and marine sediment. Relatively 


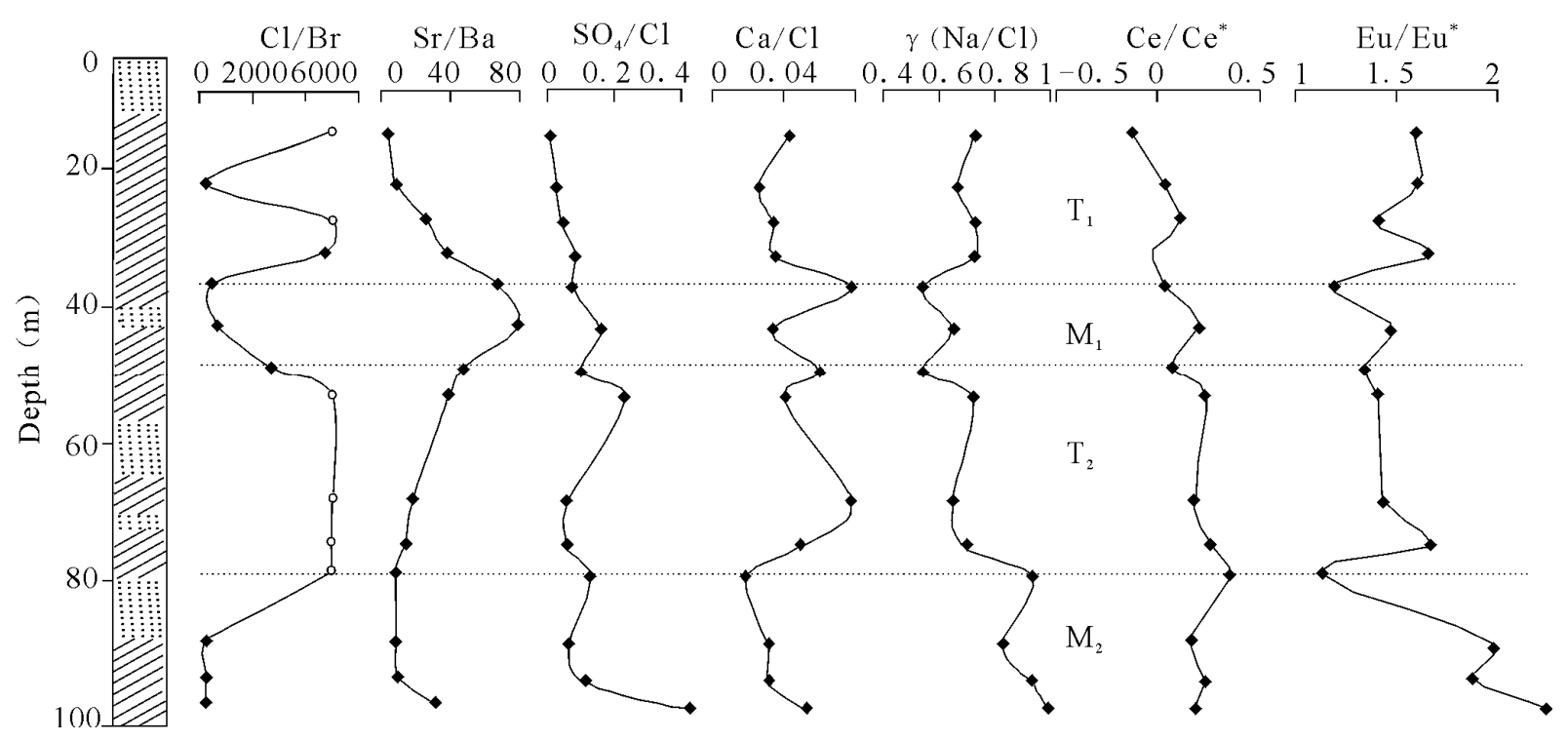

Fig. 6. Mass ratio of ions, except $\gamma(\mathrm{Na} / \mathrm{Cl})$ is for mole ratio and anomalies of Ce and Eu for aquitard pore water plotted as a function of depth $(\mathrm{m})\left(T_{1}, T_{2}, M_{1}\right.$, and $M_{2}$ shown in Fig. 2, Empty circles indicate Br- below the detection limit).

larger $\mathrm{Cl} / \mathrm{Br}$ ratios compared to Bohai seawater are caused by the diffusion and mixing of the terrestrial strata pore water. The ratios show especially large changes at the interface between marine and terrestrial sediments. Similarly, the ratios of $\mathrm{Sr} / \mathrm{Ba}$ are lower in terrestrial sediment pore waters, and they gradually increase when close to marine sediments and decrease again in terrestrial sediment pore water. Such trend of $\mathrm{Sr} / \mathrm{Ba}$ ratios further illustrates that aquitard pore water was not replaced by modern water, and the gradual process description indicates that $\mathrm{Sr}$ and $\mathrm{Ba}$ may also be subject to other roles, such as diffusion of pore water.

Controls on major ions In addition to seawater diffusion, other processes influence the major ions of aquitard pore water. $\mathrm{As} \mathrm{Cl}$ is generally a conservative element, the ratio of other ions to $\mathrm{Cl}$ can reflect the relative trends. Figure 6 shows the vertical profiles of other ions (i.e., $\mathrm{SO}_{4}{ }^{2-}, \mathrm{Ca}^{2+}$, and $\mathrm{Na}^{+}$) relative to $\mathrm{Cl}$. The trends of these ratios would explain the different geochemical reactions.

The $\gamma(\mathrm{Na} / \mathrm{Cl})$ values of aquitard pore water are 0.54 0.99 , which are greater than in Bohai seawater $(\gamma(\mathrm{Na} / \mathrm{Cl})$ $=0.52)$ and less than saline water ( 1.19 and 1.05 for $\mathrm{C} 3$ and $\mathrm{C} 4$, respectively). Overall, these values increase with depth, indicating that they are impacted by seawater diffusion. Examining Fig. 6 also shows that the trend of $\mathrm{Ca} /$ $\mathrm{Cl}$ mass ratios with depth is contrary to that of $\gamma(\mathrm{Na} / \mathrm{Cl})$; the ratios show greater change in the intersection area between marine and terrestrial sediments (Fig. 6), indicating cation exchange within the clayey aquitard. This is another process that influences the $\gamma(\mathrm{Na} / \mathrm{Cl})$ of pore water. The $\mathrm{Na}^{+}$in the pore water exchanges with $\mathrm{Ca}^{2+}$ in the sediment, leading to a smaller proportion of $\gamma(\mathrm{Na} / \mathrm{Cl})$ and a larger proportion of $\mathrm{Ca} / \mathrm{Cl}$. The average value of $\mathrm{Ca} / \mathrm{Cl}$ in pore water is 0.05 , which is slightly greater than that for seawater (0.03) and saline water (0.04).

The $\mathrm{SO}_{4} / \mathrm{Cl}$ mass ratios of pore water are generally less than 0.1 (ratio in Bohai seawater is 0.14 , and that in shallow saline groundwater is 0.39 ), suggesting that $\mathrm{SO}_{4}{ }^{2-}$ concentrations are reduced in this condition, which may result from the reduction of sulfate in the relatively closed environment of the clay-rich aquitard. $\mathrm{SO}_{4}{ }^{2-}$ reacted with organic carbon in soil to produce $\mathrm{HCO}_{3}^{-}$, which will increase the alkalinity of pore water and further saturate $\mathrm{Ca}^{2+}$ and $\mathrm{Mg}^{2+}$, resulting in precipitation. Using PHREEQC geochemical software, we calculated the saturation index of carbonate minerals (Table 1). Except for the pore water at $16.2-\mathrm{m}$ depth, calcite and dolomite in all pore waters are oversaturated (SI $>0.1$ ), which is attributed to the reduction of sulfate making the pore water more alkaline. Langmuir (1997) argued that even if a few $\mathrm{mg} / \mathrm{L}$ organic carbons were present in pore water, this would result in calcite oversaturation. Due to decreasing $\mathrm{SO}_{4}{ }^{2-}$, gypsum is not saturated $(\mathrm{SI}<-0.2)$. Therefore, the changes of $\mathrm{SO}_{4}{ }^{2-}$ are not only controlled by reduction of sulfate but also by gypsum dissolution.

$\mathrm{K}^{+}$of pore water is mainly affected by adsorption (Zhang et al., 1997) owing to the strong adsorption of clay minerals, which account for $48 \%$ of total minerals. $\mathrm{K}^{+}$ions tend to be bound in the solid phase, which is why $\mathrm{K}^{+}$concentrations are lower and stable. It was also found that $\mathrm{K}^{+}$exhibits significant positive correlation with $\mathrm{Fe}^{3+}$ $(r=0.97)$, indicating that it is also affected by coprecipitation or dissolution of iron hydroxide/oxide. 
Table 2. Trace element composition of aquitard pore water from the study site

\begin{tabular}{|c|c|c|c|c|c|c|c|c|c|c|c|c|c|c|}
\hline Depth (m) & 16.2 & 23.4 & 28.7 & 33.3 & 37.6 & 43.5 & 49.4 & 53.5 & 68.1 & 74.4 & 78.5 & 88.2 & 93.3 & 97.2 \\
\hline $\mathrm{La}(\mathrm{ppt})$ & 633 & 128 & 49 & 85 & 71 & 42 & 56 & 45 & 61 & 32 & 49 & 66 & 67 & 48 \\
\hline $\mathrm{Ce}$ & 600 & 242 & 105 & 131 & 131 & 98 & 96 & 122 & 144 & 97 & 201 & 175 & 170 & 119 \\
\hline $\operatorname{Pr}$ & 40 & 23 & 7 & 13 & 11 & 4 & 7 & 6 & 8 & 5 & 9 & 13 & 7 & 7 \\
\hline $\mathrm{Nd}$ & 202 & 112 & 36 & 47 & 69 & 29 & 25 & 27 & 28 & 35 & 72 & 46 & 35 & 25 \\
\hline $\mathrm{Sm}$ & 37 & 25 & 14 & - & 11 & - & 6 & 7 & 12 & 10 & 20 & 4 & 4 & - \\
\hline $\mathrm{Eu}$ & 396 & 147 & 57 & 66 & 61 & 39 & 45 & 32 & 53 & 60 & 34 & 97 & 77 & 34 \\
\hline $\mathrm{Gd}$ & 48 & 6 & 6 & 10 & 23 & 9 & 11 & 4 & 5 & 1 & 3 & 5 & 5 & 1 \\
\hline $\mathrm{Tb}$ & 5 & 3 & 1 & 2 & 2 & 1 & 1 & 1 & 1 & 1 & 2 & 1 & 2 & 1 \\
\hline Dy & 43 & 12 & 2 & 14 & 8 & 9 & - & 4 & 1 & - & 4 & - & 5 & 3 \\
\hline Ho & 7 & 2 & 2 & 2 & 2 & - & 1 & 0 & - & 2 & 3 & - & - & - \\
\hline $\mathrm{Er}$ & 33 & 19 & 10 & 10 & 11 & 13 & 11 & 12 & 6 & 14 & 14 & 18 & 13 & 17 \\
\hline $\mathrm{Tm}$ & 4 & 3 & 2 & 1 & 1 & 0 & 1 & 2 & 1 & 1 & 1 & 2 & 1 & 1 \\
\hline $\mathrm{Yb}$ & 32 & 29 & 16 & 8 & 12 & 8 & 7 & 8 & 2 & 3 & 5 & 9 & 9 & 12 \\
\hline $\mathrm{Lu}$ & 5 & 3 & 1 & 2 & 2 & 2 & 2 & 1 & - & 1 & 3 & 2 & 1 & 1 \\
\hline $\mathrm{Sr}(\mathrm{ppm})$ & 9.28 & 7.15 & 8.58 & 11.82 & 21.68 & 13.92 & 9.58 & 6.67 & 5.60 & 4.05 & 1.91 & 4.94 & 4.45 & 5.03 \\
\hline $\mathrm{Ba}(\mathrm{ppm})$ & 2.25 & 0.83 & 0.33 & 0.31 & 0.32 & 0.17 & 0.20 & 0.17 & 0.31 & 0.30 & 0.23 & 0.53 & 0.45 & 0.16 \\
\hline$\sum \mathrm{REE}(\mathrm{ppb})$ & 2.08 & 0.75 & 0.31 & 0.39 & 0.42 & 0.25 & 0.27 & 0.27 & 0.32 & 0.26 & 0.42 & 0.44 & 0.40 & 0.27 \\
\hline $\mathrm{Eu} / \mathrm{Eu}^{*}$ & 1.60 & 1.62 & 1.40 & 1.69 & 1.18 & 1.49 & 1.34 & 1.41 & 1.46 & 1.67 & 1.13 & 1.98 & 1.86 & 2.25 \\
\hline $\mathrm{Ce} / \mathrm{Ce}^{*}$ & -0.13 & 0.03 & 0.12 & -0.03 & 0.05 & 0.21 & 0.06 & 0.25 & 0.18 & 0.26 & 0.35 & 0.16 & 0.25 & 0.19 \\
\hline$(\mathrm{La} / \mathrm{Yb})_{\mathrm{NASC}}$ & 1.71 & 0.38 & 0.26 & 0.97 & 0.53 & 0.44 & 0.70 & 0.51 & 2.18 & 0.80 & 0.88 & 0.60 & 0.62 & 0.35 \\
\hline
\end{tabular}

$E u / E u^{*}=\log \left\{2 E u_{S N} /\left(S m_{N A S C}+G d_{N A S C}\right)\right\} ; C e / C e^{*}=\log \left\{2 C e_{N A S C} /\left(L a_{N A S C}+P r_{N A S C}\right)\right\}$.

NASC: North American Shale Composite normalized.

- indicates concentration below detection limits.

The REE values (in ppm) of the North American Shale Composite used in this paper for normalization are La (32), Ce (73), $\mathrm{Pr}$ (7.9), Nd (33), Sm (5.7), Eu (1.24), Gd (5.2), Tb (0.85), Dy (5.8), Ho (1.04), Er (3.4), Tm (0.5), Yb (2.8), and Lu (0.48) (Willis and Johannesson, 2011; Taylor and McLennan, 1985).

\section{REE of aquitard pore water}

REE concentrations Rare earth element concentrations of aquitard pore water in this study area are low (Table 2 ). The highest REE content was found in pore water from 16.2-m depth. The total REE ( $\Sigma \mathrm{REE}$ ), for example, reaches $2.08 \mathrm{ppb}$. At depths greater than $16.2 \mathrm{~m}$, the $\sum$ REE of pore water is $0.26-0.42 \mathrm{ppb}$. The distinctly higher REE contents of the shallowest water sample are likely due to the unique acidic water condition. The correlation coefficients for individual REEs and $\mathrm{pH}$ demonstrate that, overall, REEs are negatively associated with $\mathrm{pH}$ in pore water (e.g., Fig. 7a). These negative correlations are in contrast to the previously reported positive relationship between REE concentrations and $\mathrm{pH}$ in till pore water (Johannesson and Hendry, 2000). Generally, the lower pH of pore water would increase the ability to accelerate water-rock interaction, prompting REE activation and migration as complexes or free ions. Hannigan et al. (2010) demonstrated that salinity gradient was an important factor in the transport of REEs. As can be seen from Figs. $7 \mathrm{~b}$ and $\mathrm{c}$, although the TDS of pore water has a wide range, REE displays a weak relationship with TDS (dominated by diffusion of seawater) and significant positive correlations with $\mathrm{Ba}, \mathrm{Fe}$, and $\mathrm{Zn}$ (only $\mathrm{Ba}$ is plotted), illustrating that REE contents of pore water in this area are controlled by dissolution or desorption of minerals. In addition, Pourret et al. (2010), Dia et al. (2000), and
Johannesson and Hendry (2000) reported that colloids and organic matter in clayey soils mainly impacted the REE concentrations, based on their large adsorption capacity. Those indicators were not tested in the present study; however, from Table 2, it is clear that, for most pore water samples, REE concentrations are higher in clay formations than in silt sand. This may be caused by colloids or organic matter owing to their enrichment in the finegrained sediment (Yan et al., 2000).

Changes in oxidation states of $\mathrm{Eu}^{3+}$ to $\mathrm{Eu}^{2+}$ and $\mathrm{Ce}^{3+}$ to $\mathrm{Ce}^{4+}$ are useful indicators in analyzing pore water geochemistry (Sako et al., 2009). Under oxidizing and high $\mathrm{pH}$ conditions, $\mathrm{Ce}$ can coprecipitate with $\mathrm{Fe}-$ and $\mathrm{Mn}$-oxyhydroxides as insoluble $\mathrm{CeO}_{2}$, producing a negative $\mathrm{Ce}$ anomaly in pore water. Therefore, $\mathrm{Ce} / \mathrm{Ce} *(\mathrm{Ce} /$ $\left.\mathrm{Ce}^{*}=\log \left\{2 \mathrm{Ce}_{\mathrm{NASC}} /\left(\mathrm{La}_{\mathrm{NASC}}+\operatorname{Pr}_{\mathrm{NASC}}\right)\right\}\right)$ values greater than 0.1 in most pore waters exhibiting positive Ce anomalies suggest a relative reducing environment in aquitard pore water (Fig. 6). If redox plays a role in the resuspension of $\mathrm{Ce}^{3+}$ to the water column, we would expect to see a relationship between $\mathrm{Ce}$ and redox-sensitive trace metals such as Fe and Mn. From Figs. $7 d-f$, it is seen that $\mathrm{Ce} / \mathrm{Ce} *$ ratios bear no relation to REE and, overall, they decrease with increasing $\mathrm{Fe}$ and Mn concentrations, indicating that $\mathrm{Ce}$ was released to pore water by the reductive dissolution of $\mathrm{Fe}$ and $\mathrm{Mn}$ oxyhydroxides. And $\mathrm{Ce}$ is preferentially absorbed on the coatings of or- 
(a)

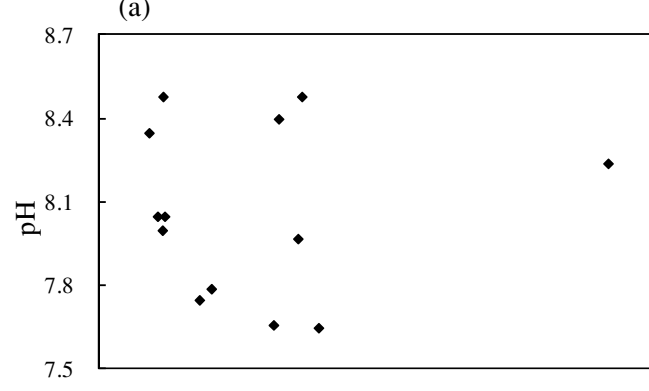

(b)

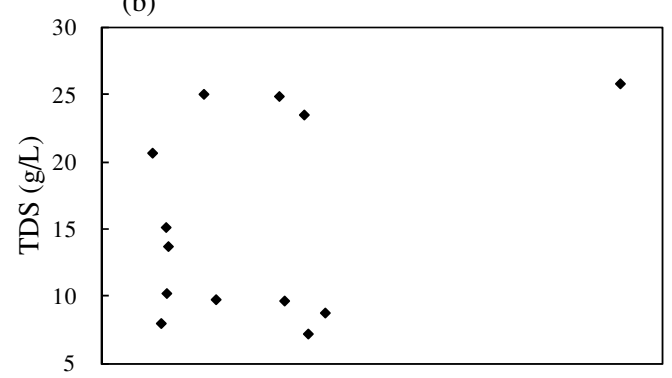

(c)

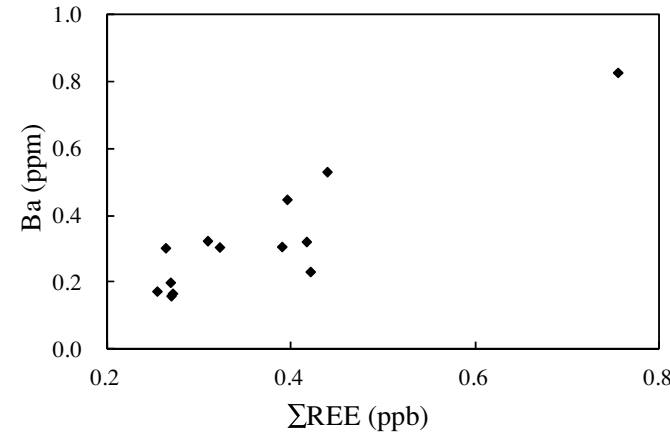

(d)

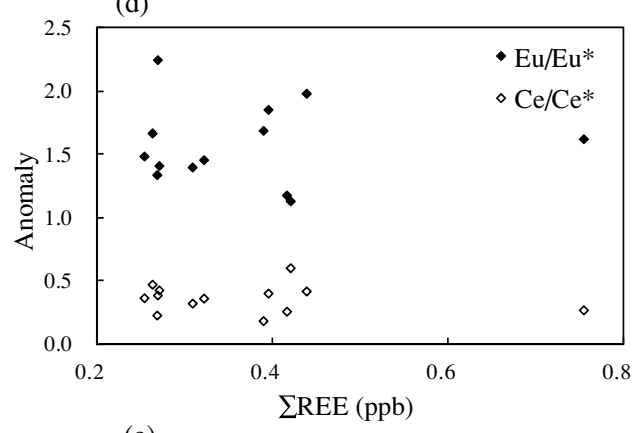

(e)

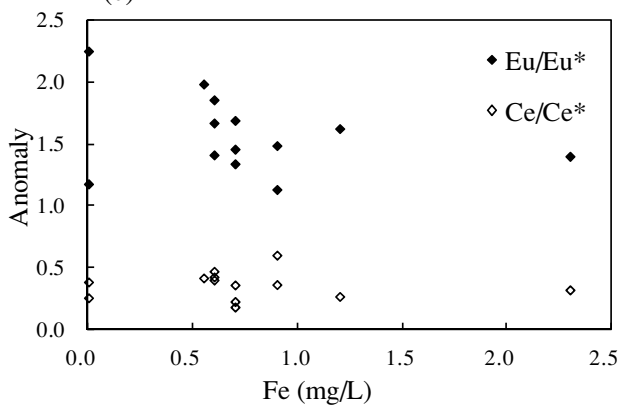

(f)

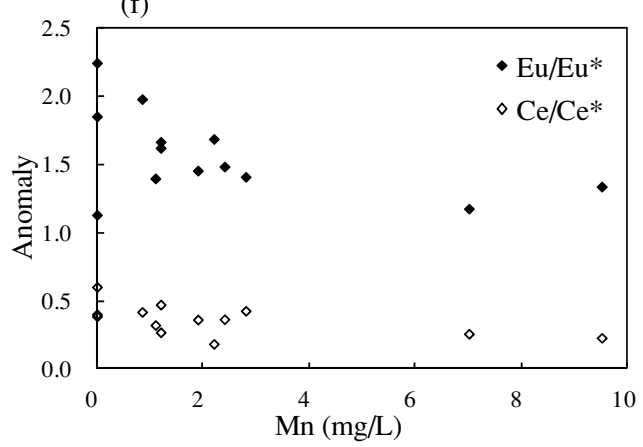

Fig. 7. Relationships between REE and $\mathrm{pH}, T \mathrm{DS}, \mathrm{Ba}, \mathrm{Eu} / \mathrm{Eu^{* }}$, and $\mathrm{Ce} / \mathrm{C} \mathrm{e}^{*}$ values and relationships between anomalous (including $E u$ and $\mathrm{Ce}$ ) and $\mathrm{Fe}$ and Mn concentration for aquitard pore water (the shallowest pore water sample was excluded owing to the influence of anthropogenic inputs).

ganic matter or particle surfaces, less mobile than Fe and $\mathrm{Mn}$, leading to a moderate inverse relationship among these variables.

Distinct positive Eu anomalies were found in all the aquitard pore waters, with an average value of 1.58 (Fig. 6). Guo et al., (2010) suggested that in the reducing pore water, Eu would cause preferential mobilization of $\mathrm{Eu}^{2+}$ relative to the more particle-reactive trivalent REEs. The mobilization would be related to water-rock interaction. As seen from Fig. 6, Eu/Eu* $\left(\mathrm{Eu} / \mathrm{Eu}^{*}=\log \left\{2 \mathrm{Eu}_{\mathrm{NASC}}\right\}\right.$ $\left.\left.\left(\mathrm{Sm}_{\mathrm{NASC}}+\mathrm{Gd}_{\mathrm{NASC}}\right)\right\}\right)$ values show a positive relationship with REE, indicating that Eu anomalies are affected by the dissolution of minerals, especially plagioclase (accounting for $15 \%$ of the total minerals), thereby preferentially accumulating Eu (Taylor and McLennan, 1988). Conversely, from the negative relationship of $\mathrm{Eu} / \mathrm{Eu}^{*}$ ra- tios and $\mathrm{Fe}$ and $\mathrm{Mn}$ contents, we can conclude that the adsorption of $\mathrm{Fe}$ and $\mathrm{Mn}$ oxyhydroxides also strongly impacts the Eu element.

Shale-normalized REE fractionation patterns Shalenormalized REE fractionation patterns for aquitard pore water samples are presented in Fig. 8. Here, we use the North American Shale Composite (NASC; Taylor and Mclennan, 1985). The composite shale used to normalize groundwater REE concentrations represents the Average Shale, and it has been employed recently in many groundwater studies (Rönnback et al., 2008; Guo et al., 2010), particularly for pore water from clay-rich aquitards, for which it represents a relatively good normalizing standard (Johannesson and Hendry, 2000).

Previous investigation suggested that groundwaters inherit "rock-like" REE fractionation patterns near the 

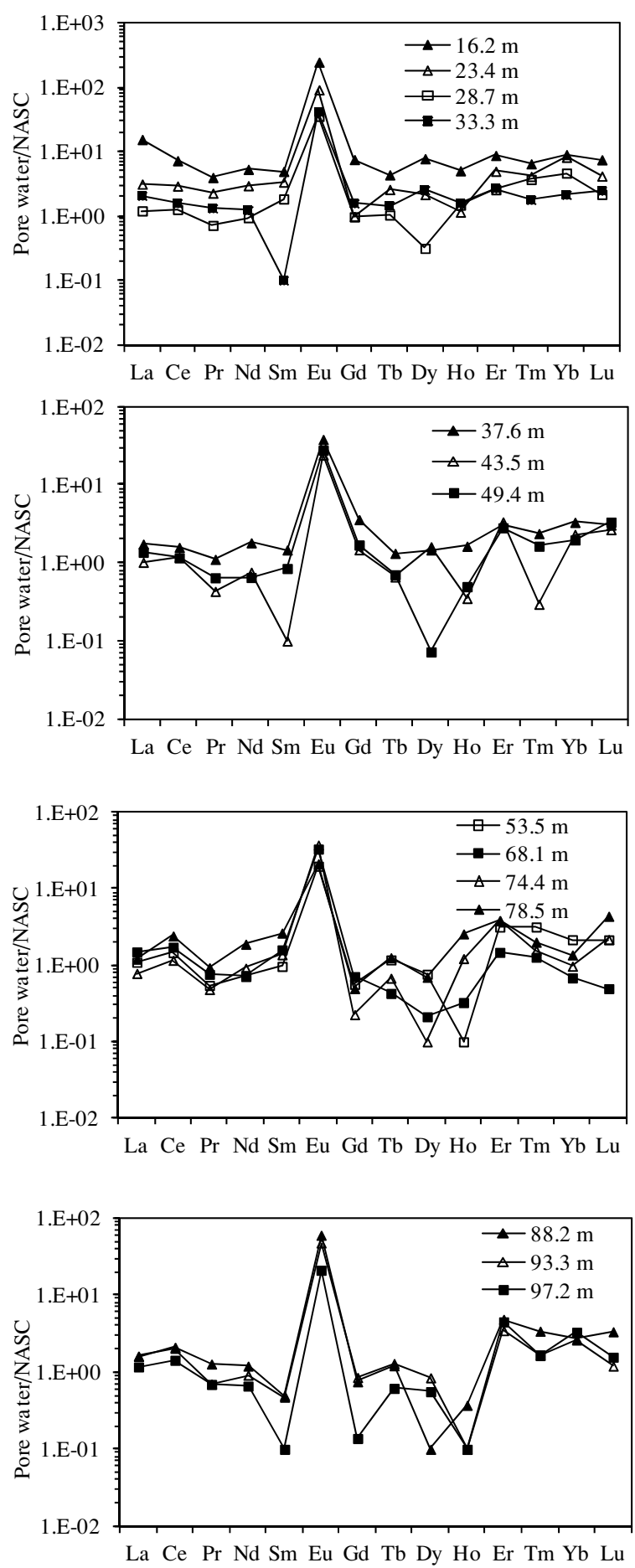

Fig. 8. Shale-normalized REE plots of aquitard pore water from the study site (content of pore water $\times 10^{6}$ ).

end of the flow paths, prior to discharge (Banner et al., 1989). Other studies demonstrated that groundwater REE patterns actually evolve along flow paths as geochemical reactions between these groundwaters and aquifer rocks modify the chemical composition of the flowing groundwater (Willis and Johannesson, 2011). However, as Fig. 3 showed, not all of the pore water samples have a "rocklike" shale-normalized REE pattern (characterized by LREE enrichment and negative Eu anomalies of the study area sediments; Zhao et al., 1990) or "seawater-like" (actually strongly negative $\mathrm{Ce}$ anomalies) fractionation patterns. They were characterized by enrichment in HREE relative to LREE when compared to NASC. The value of $(\mathrm{La} / \mathrm{Yb})_{\text {NASC }}$ is between 0.25 and 2.18 (Table 2). The most obvious feature of shale-normalized REE patterns is the strongly positive Eu anomaly. Moreover, excluding the $\mathrm{Eu}$ anomalies, REE fractionation patterns of pore water in this aquitard sequence show diverse fractionation in different sediment units. For example, shale-normalized HREEs are much more enriched in pore water of marine sediments compared to terrestrial sediment owing to the complexation with $\mathrm{HCO}_{3}{ }^{-}$of HREEs. Furthermore, there is a strong Ho loss in marine sediment pore waters as well as pore water located at the interface of marine and terrestrial sediments (i.e., $53.5-\mathrm{m}$ depth).

It is common for HREEs to show enrichment in clayrich aquitard pore water relative to LREEs. One explanation is that LREEs show greater affinity than HREE to adsorb onto clay minerals or coatings on clay minerals, resulting in the depletion of LREE. In addition, shalenormalized HREE shows much greater enrichment in marine sediment pore waters relative to terrestrial sediment. This is because carbonate complexes are the dominant form of dissolved REE in seawater; furthermore, for REEs heavier than $\mathrm{Gd}$, dicarbonato complexes become progressively more important with increasing atomic number compared to carbonato complexes (i.e., $\mathrm{LnCO}_{3}{ }^{+}$). In this case, $\mathrm{LnCO}_{3}{ }^{+}$complexes mostly with LREEs are more easily adsorbed onto the negative-charged clay minerals than are HREEs, which are mostly in the form of $\left[\mathrm{Ln}\left(\mathrm{CO}_{3}\right)_{2}\right]^{-}$; as Table 2 shows, $(\mathrm{La} / \mathrm{Ya})_{\mathrm{NASC}}$ ratios decrease with increasing $\mathrm{HCO}_{3}^{-}$concentrations.

\section{CONCLUSIONS}

Pore water was extracted from core samples from a clay-rich aquitard in Caofeidian Harbor, China, using the mechanical squeezing method at $2.12 \mathrm{MPa}$. The relationship between ${ }^{18} \mathrm{O}$ and $\mathrm{D}$ shows that the aquitard pore water was of meteoric origin, and it was not affected by evaporation. The $\delta^{18} \mathrm{O}$ profile exhibits a decreasing trend with depth, from $-3.03 \%$ to $-9.98 \%$. Together with positive correlation (0.93) between $\delta^{18} \mathrm{O}$ and $\mathrm{Cl}^{-}$, this indicates that the pore water isotope signature was mainly controlled by seawater diffusion, which differs with shallow groundwater intrusion by seawater with advection transport. The greater depletion of the pore water ${ }^{18} \mathrm{O}$ value than that of saline water or seawater indicates that the 
aquitard pore water may be paleo-water that was not replaced by modern water.

In terrestrial sediments, the pore water $\mathrm{Cl} / \mathrm{Br}$ ratio with depth reaches 4750 or tends to infinity, whereas in marine sediments, it is 270-510 owing to the interaction between pore water and sediment, suggesting that pore water was not replaced by modern water or seawater during long-term residence in the aquitard. This is further supported by the finding that $\mathrm{Sr} / \mathrm{Ba}$ ratios of pore water show different trends in different sedimentary facies.

High TDS was found in pore water, with the shallowest sample being close to seawater. The vertical profile of TDS shows a decreasing trend, from 26.89 to $7.26 \mathrm{~g} /$ L. The same trend was observed for $\mathrm{Cl}^{-}, \mathrm{Na}^{+}$, and $\mathrm{Mg}^{2+}$; it was caused by the diffusion of seawater. In addition to seawater, other processes influence the major ions of pore water, such as reduction of sulfates and cation exchange, which are responsible for $\mathrm{SO}_{4}{ }^{2-}, \mathrm{Ca}^{2+}$, and $\mathrm{Na}^{+}$, respectively.

REE concentrations of pore water are mainly affected by water-rock interaction and desorption of clay minerals. The slightly positive $\mathrm{Ce} / \mathrm{Ce}^{*}$ is expected to account for the relatively reducing condition in the aquitard; under this condition, preferential mobilization of $\mathrm{Eu}^{2+}$ relative to the trivalent REEs leads to the development of positive $\mathrm{Eu} / \mathrm{Eu}^{*}$. Shale-normalized REE patterns are characterized by HREE enrichment and LREE depletion for all pore waters, and the greater degree of fractionation (i.e., larger $\mathrm{La} / \mathrm{Yb}_{\mathrm{NASC}}$ ) for pore water extracted from marine sediment can be attributed to the distinct adsorption onto particle surfaces for LREEs and preferable complexation with the inorganic or organic matter in the solution for HREEs.

Acknowledgments - This study was financially supported by the National Natural Sciences Foundation of China (41272258) and the National Basic Research Program of China (2010CB428802). The authors would like to thank the Tianjin Geological Survey Center for drilling and sampling of the aquitard, and Mr. Cong Wang for laboratory assistance.

\section{REFERENCES}

An, F. T., Gao, S. M. and Li, Y. F. (1982) Research on the depositional environment of Luanhe River delta by analyzing of trace elements. Trans. Oceanol. Limnol. 2, 2431 (in Chinese).

Augustsson, A., Bergback, B. and Astrom, M. (2009) Trace metals in recharge and discharge ground waters at two sites at the Baltic coast of Sweden. Appl. Geochem. 24(9), 16401652.

Banner, J. L., Wasserburg, G. J., Dobsn, P. F., Carpenter, A. B. and Moore, C. H. (1989) Isotopic and trace element constraints on the origin and evolution of saline groundwaters from central Missouri. Geochim. Cosmochim. Acta 53, 383389.
Biddau, R., Bensimon, M., Cidu, R. and A. Parriaux (2009) Rare earth elements in groundwater from different Alpine aquifers. Chemie der Erde-Geochem. 69(4), 327-339.

Bufflap, S. E. and Allen, H. E. (1995) Sediment pore water collection methods for metal analysis: a review. Water Res. 29(1), 165-177.

Chen, Z. Y. (2001) Groundwater resources evolution based on paleoenvironmental information from groundwater system in the north china plain. Ph.D. Dissertation, Jilin University.

Cherry, J. A., Parker, B. L., Bradbury, K. R., Eaton, T. T., Gotkowitz, M. B., Hart, D. J. and Borchardt, M. A. (2006) Contaminant Transport through Aquitards: A "State of the Science Review". AWWA Research Foundation, Denver, Colorado.

Craig, H. (1961) Standard for reporting concentration of deuterium and oxygen-18 in natural water. Science 133, 18331834.

Dia, A., Gruau, G., Olivié-Lauquet, G., Riou, C., Molénat, J. and Curmi, P. (2000) The distribution of rare earth elements in groundwaters: Assessing the role of source-rock composition, redox changes and colloidal particles. Geochim. Cosmochim. Acta 64(24), 4131-4151.

Gao, Y. X., Wang, G. L., Liu, H. T., Zhang, J. P. and Zuo, W. J. (2004) Chemical characteristics of groundwater in the western Tangshan. J. Arid Land Resour. Environ. 18(3), 78-81 (in Chinese).

Guerrero, A., Cherry, J. A. and Aravena, R. (1997) Origin of pore water and salinity in the lacustrine aquitard overlying the regional aquifer of Mexico City. J. Hydrol. 197(1-4), 47-69.

Guerrero, A., Cherry, J. A., Rudolph, D. L. (2005) Large-scale aquitard consolidation near Mexico City. Ground Water 31(5), 708-718.

Guo, H., Zhang, B., Wang, G. and Shen, Z. (2010) Geochemical controls on arsenic and rare earth elements approximately along a groundwater flow path in the shallow aquifer of the Hetao Basin, Inner Mongolia. Chem. Geol. 270(1-4), 117125 (in Chinese).

Guo, Y. H., Shen, Z. L. and Zhong, Z. Y. (1995) The property of deep groundwater in Hebei plain and its reasonable evaluation in view of land subsidence. Earth Science - Journal of China University of Geosciences 20(4), 419-420 (in Chinese).

Hannigan, R., Dorval, E. and Jones, C. (2010) The rare earth element chemistry of estuarine surface sediments in the Chesapeake Bay. Chem. Geol. 272(1-4), 20-30.

Hendry, M. J. and Wassenaar, L. I. (1999) Implications of the distribution of $\delta \mathrm{D}$ in pore waters for groundwater flow and the timing of geologic events in a thick aquitard system. Water Resour. Res. 35(6), 1751-1760.

Hendry, M. J. and Wassenaar, L. I. (2004) Transport and geochemical controls on the distribution of solutes and stable isotopes in a thick clay-rich till aquitard, Canada. Isotopes Environ. Health Stud. 40(1), 3-19.

Hendry, M. J. and Wassenaar, L. I. (2011) Millennial-scale diffusive migration of solutes in thick clay-rich aquitards: evidence from multiple environmental tracers. Hydrogeol. J. 19(1), 259-270. 
Hendry, M. J. and Woodbury, A. D. (2007) Clay aquitards as archives of Holocene paleoclimate: $\delta^{18} \mathrm{O}$ and thermal profiling. Groundwater 45(6), 683-691.

Hiscock, K. M., George, M. A. and Dennis, P. F. (2011) Stable isotope evidence for the hydrogeological characteristics of clay-rich till in northern East Anglia. Quart. J. Eng. Geol. Hydrogeol. 44(2), 173-189.

Jiao, J. J., Wang, Y., Cherry, J. A., Wang, X., Zhi, B., Du, H. and Wen, D. (2010) Abnormally high ammonium of natural origin in a coastal aquifer-aquitard system in the Pearl River Delta, China. Environ. Sci. Technol. 44(19), 7470-7475.

Johannesson, K. H. and Hendry, M. J. (2000) Rare earth element geochemistry of groundwaters from a thick till and clay-rich aquitard sequence, Saskatchewan, Canada, Geochim. Cosmochim. Acta 64(9), 1493-1509.

Johannesson, K. H., Stetzenbach, K. J. and Hodge, V. F. (1997) Rare earth elements as geochemical tracers of regional groundwater mixing. Geochim. Cosmochim. Acta 61(17), 3605-3618.

Johannesson, K. H., Chevis, D. A,, Burdige, D. J., Cablec, J. E., Martind, J. B. and Royd, M. (2011) Submarine groundwater discharge is an important net source of light and middle REEs to coastal waters of the Indian River Lagoon, Florida, USA. Geochim. Cosmochim. Acta 75(3), 825-843.

Kelln, C. J., Wassenaar, L. I. and Hendry, M. J. (2001) Stable isotopes $\left(\delta^{18} \mathrm{O}, \delta^{2} \mathrm{H}\right)$ of pore water in clay-rich aquitards: A comparison and evaluation of measurement techniques. Spring GWMR 21(2), 108-116.

Langmuir, D. (1997) Aqueous Environmental Geochemistry. Prentice-Hall, Englewood Cliffs, N.J.

Lee, J. H. and Byrne, R. H. (1992) Examination of comparative rare-earth element complexation behavior using linear free-energy relationships. Geochim. Cosmochim. Acta 56(3), 1127-1137.

Leybourne, M. I. and Cameron, E. M. (2010) Groundwater in geochemical exploration. Geochem. Exp. Environ. Anal., 10(2), 99-118.

Li, L. and Li, C. C. (2008) Analysis on regional geological environment in Caofeidian industrial area of TangShan. Resour. Industries 10(1), 25-27 (in Chinese).

Lopes, I. and Ribeiro, R. (2005) Optimization of a pressurization methodology for extracting pore-water. Chemosphere 61(10), 1505-1511.

McMahon, P. B. and Chapelle, F. H. (1991) Microbial production of organic acids in aquitard sediments and its role in aquifer geochemistry. Nature 349, 233-235.

Parker, B. L., Chapman, S. W. and Guilbeault, M. A. (2008) Plume persistence caused by back diffusion from thin clay layers in a sand aquifer following TCE source-zone hydraulic isolation. J. Contam. Hydrol. 102(1-2), 86-104.

Pourret, O., Gruau, G., Dia, A., Davranche, M. and Molénat, J. (2010) Colloidal control on the distribution of rare earth elements in shallow groundwaters. Aqua. Geochem. 16(1), 31-59.

Remenda, V. H., Kamp, G. V. and Cherry, J. A. (1996) Use of vertical profiles of $\delta^{18} \mathrm{O}$ to constrain estimates of hydraulic conductivity in a thick, unfractured aquitard. Water Resour. Res. 32(10), 2979-2987.

Rönnback, P., Åström, M. and Gustafsson, J. (2008) Compari- son of the behaviour of rare earth elements in surface waters, overburden groundwaters and bedrock groundwaters in two granitoidic settings, Eastern Sweden. Appl. Geochem. 23(7), 1862-1880.

Rübel, A. P., Sonntag, C., Lippmann, J., Pearson, F. J. and Gautschi, A. (2002) Solute transport in formations of very low permeability: Profiles of stable isotope and dissolved noble gas contents of pore water in the Opalinus Clay, Mont Terri, Switzerland. Geochim. Cosmochim. Acta 66(8), 13111321.

Sacchi, E., Michelot, J. L., Pitsch, H. (2001) Extraction of water and solutes from argillaceous rocks for geochemical characterization: Methods, processes, and current understanding. Hydrogeol. J. 9(1), 17-33.

Sako, A., Mills, A. J. and Roychoudhury, A. N. (2009) Rare earth and trace element geochemistry of termite mounds in central and northeastern Namibia: Mechanisms for micronutrient accumulation. Geoderma 153(1-2), 217-230.

Savoye, S., Michelot, J. L., Bensenouci, F., Lalieux, P. and Aranyossy, J.-F. (2008) Transfers through argillaceous rocks over large space and time scales: Insights given by water stable isotopes. Phys. Chem. Earth 33, 67-74.

Shen, Z. Z., Li, J., Liang, X., Mao, X. M., Wang, C. and Zhang, Y. N. (2011) An piston mechanical squeeze for extracting ptore-water of clayey rock. China, 201020607732.4[P] (in Chinese).

Stetzenbach, K. J., Amano, M., Kreamer, D. K. and Hodge, V. F. (1994) Testing the limits of ICP-MS determination of trace elements in ground water at the parts-per-trillion level. Ground Water 32(6), 976-985.

Taylor, S. R. and McLennan, S. M. (1985) The Continental Crust: Its Composition and Evolution. Blackwell Scientific Publications, Oxford. 312 pp.

Taylor, S. R. and McLennan, S. M. (1988) Handbook on the Physics and Chemistry of Rare Earths (Gschneidner, K. A., Jr. and Eyring, L., eds.), Vol. 11, 485-578, Elsevier, Amsterdam.

Timms, W. A. and Hendry, M. J. (2008) Long-term reactive solute transport in an aquitard using a centrifuge model. Ground Water, 46(4), 616-628.

Waber, H. N. and Smellie, J. A. (2008) Characterisation of pore water in crystalline rocks. Appl. Geochem. 23(7), 18341861.

Wang, Y. (2000) Evolution sequences of palaeovegetation and palaeoclimate in the Caofeidian area since the last stage of the late Pleistocene epoch. Mar. Geol. Quater. Geol. 20(2), 87-92 (in Chinese).

Wang, Y., Ke, X. K. and Jia, Y. L. (1999) Study on the coastal profile changes of the Caofeidian Area in the Bohai Sea since 1983. Mar. Sci. Bull. 18(1), 43-51 (in Chinese).

Willis, S. S. and Johannesson, K. H. (2011) Controls on the geochemistry of rare earth elements in sediments and groundwaters of the Aquia aquifer, Maryland, USA. Chem. Geol. 285(1-4), 32-49.

Yan, X. P., Kerrich, R. and Hendry, M. J. (2000) Distribution of the rare earth elements in porewaters from a clay-rich aquitard sequence, Saskatchewan, Canada. Chem. Geol. 176(1-4), 151-172.

Yan, X. X. and Huo, J. L. (2007) Analysis for characteristics of 
physiognomy and sediment in offshore area of Hebei Caofeidian. Journal of Waterway and Harbor 3(28), 164168 (in Chinese).

Yang, I. C., Peterman, Z. E. and Scofield, K. M. (2003) Chemical analyses of pore water from boreholes USW SD-6 and USW WT-24, Yucca Mountain, Nevada. J. Contam. Hydrol. 62-63, 361-380.

Zhang, W. J., Sun, X. M., Liu, F. T., Zhang, W. and Fang, C. (2010) Application of R mode analysis on chemical characters and influential factors of quaternary groundwater in Caofeidian area. Safe. Environ. Eng. 17(1), 1-5 (in Chinese).
Zhang, Z.-H., Shi, D.-H., Shen, Z.-L., Zhong, Z.-S. and Xue, Y.-Q. (1997) Evolution and development of groundwater environment in North China Plain under human activities. Acta Geosci. Sinica 18(4), 337-344 (in Chinese).

Zhao, Y. Y., Wang, J. T., Qin, C. Y., Chen, Y. W., Wang, X. J. and Wu, M. Q. (1990) Rare-earth elements in continental shelf sediments of the china seas. Acta Sediment Sinica $\mathbf{8}(1)$, 37-43 (in Chinese).

Zhou, L., Liu, C. F. and Wang, P. Y. (1998) Isotopic composition of saline water in North China Plain. Hydrogeol. Eng. Geol. 3, 4-7 (in Chinese). 